\title{
Penerimaan dan Penolakan Homoseksual Berbasis Pengalaman Pribadi Teologi Kekristenan dari Sisi Pendetaan Agama Kristen
}

\author{
Helen Diana Subekti ${ }^{*}$, Endah Triwijati ${ }^{1}$, Teguh Wijaya Mulya ${ }^{1}$ \\ ${ }^{1}$ Fakultas Psikologi Universitas Surabaya, Raya Kalirungkut, Surabaya - Indonesia 60293 \\ *Corresponding author: helendiana96@gmail.com
}

\begin{abstract}
In these past few years, issues regarding homosexuality are growingrapidly. These issues, of course, cannot be taken lightly nor be ignored anymore asthey are slowly but surely surrounding us all. Looking through religion's shoes-as religion cannot be taken away from Indonesian's lifestyle that ideally upholdingthe values ofPancasila, many condemning homosexuality, and Christian is one ofmany religions that also refuse and condemn the act of it. In popular Christiandoctrine, it is said that homosexuality is a form of sin and brings sorrow to the heart of Christ. However, is it really the only doctrine about homosexuality in Christian?The answer is no. There is another doctrine which is more accepting and welcominghomosexuals as a part of them, and people barely have their feet submerged in thisone. This doctrine is never really discussed. Therefore, this research exists. Thereare two participants of this research. Both of them are priests and come from twodifferent doctrines and perspectives; accepting and condemning homosexual. Thisresearch is using priest as the participant because of their knowledge are assumedas suffice to gain the title and they are the biggest agent to spread the gospel whichpeople usually listen and look up to.
\end{abstract}

Keywords: homosexuality, christianity, condemning homosexual, accepting homosexual, christian theology

Abstrak-Dalam beberapa tahun belakangan ini, isu homoseksual berkembangsangat pesat. Isu ini tentu tidak dapat dihindari lagi. Tidak mungkin untuk masyarakat terus-terusan menutup mata. Melihat dari sisi agama yang tidak dapat lepas dari kehidupan masyarakat Indonesia yang idealnya menjunjung tinggi Pancasila dalam kehidupan sehari-hari, banyak ajaran agama yang menolak homoseksual secara tegas-ajaran agama Kristen salah satunya. Dalam ajaran Kristen yang dominan diyakini umat, perilaku homoseksual adalah sebuah dosa dan benar-benar mendukakan hati Tuhan. Namun, apakah ajaran tersebut adalah satu- satunya ajaran mengenai homoseksual yang ada di dalam Kristen? Tidak. Ada ajaran lain yang mendukung kaum homoseksual dan tidak banyak yang tahu mengenai ajaran tersebut. Maka dari itu, penelitian ini ada untuk mengisi kekosongan ilmu tersebut. Ada dua pendeta yang akan diwawancarai. Dua pendeta tersebut berasal dari dua kubu yang berbeda, yaitu kubu yang menerima dan yang menolak homoseksual. Penelitian ini menggunakan pendeta sebagai narasumber karena dalam suatu praktik keagamaan, pendeta adalah agen terbesar dalam menyebarkan ajaran agama atau teologi. Mereka dijunjung tinggi sebagai seseorang yang memiliki dampak terbesar kepada umat-umat pemeluk agama Kristen. Halhal yang dikatakan oleh pemimpin agama sering kali langsung diamini oleh umat

Kata kunci: homoseksual, pendeta, penerimaan homoseksual, penolakan homoseksual, teologi kekristenan

\section{PENDAHULUAN}

Penelitian ini dilatarbelakangi oleh peneliti yang memiliki konflik internal terkait dengan penerimaan dan penolakan kaum homoseksual dari sisi agama. Isu tentang homoseksual sudah tidak asing di telinga masyarakat melalui media, seperti televisi, surat kabar, dan internet. Opini masyarakat secara umum bermacam-macam, ada yang menolak dengan keras dan ada pula yang menerima dengan berbagai alasan.

Beberapa negara di dunia bagian barat, salah satunya Argentina telah mengesahkan pernikahan sejenis sejak tahun 2010 silam. Argentina adalah negara Amerika Latin pertama yang melegalkan dan memberikan hak-hak terhadap pasangan sejenis, seperti mengadopsi anak dan memperoleh warisan dari pasangannya selayaknya pasangan heteroseksual (Tim Viva, 2010). Di sisi lain, beberapa negara seperti Afganistan, Iran, Nigeria, Qatar, Arab dan beberapa negara timur tengah lainnya menganggap bahwa perilaku homoseksual adalah perilaku yang melanggar hukum sehingga perlu diberikan hukuman mati. Hukum-hukum dan aturan yang berada di negara-negara tersebut didasari oleh ajaran agama Islam (Cameron \& 
Berkowitz, 2016) yang mengatakan bahwa seluruh hubungan seksual di luar hubungan pernikahan heteroseksual adalah zina dan dapat dihukum dengan hukum Islam (shariah) (Bennett, 2005) sehingga mereka tidak menerima keberadaan kaum homoseksual.

Indonesia pun tidak lepas dari pro dan kontra isu ini. Sebagian masyarakat menolak kaum homoseksual dengan keras. Sejak awal 2016, kekerasan yang dialami oleh kaum LGBT kian marak terjadi. Menurut Erdianto (2016), tercatat sebanyak 142 kasus (selama Januari Maret 2016) penangkapan, penyerangan, diskriminasi, pengusiran dan ujaran kebencian yang ditujukkan kepada kelompok LGBT. Meskipun begitu, ada sebagian masyarakat yang mendukung atau pro pemenuhan hak asasi kaum homoseksual. Mulai dari pergerakan yang berbentuk kelompok-kelompok studi gender yang berada di dalam beberapa universitas. Selain dari pergerakan beberapa universitas tersebut ada pula contoh-contoh organisasi luar kampus yang juga pro dengan kaum homoseksual, yaitu Gaya Warna Lentera atau GWL-INA (2007), Ardhanary Institute, hingga Komnas HAM yang berulang kali mendesak pemerintah untuk melindungi masyarakat LGBT (Erdianto, 2016).Tidak hanya dalam masyarakat umum, Gereja pun terbelah dua; menerima dan menolak. Isu homoseksual ini cukup menjadi bahan pembicaraan yang tiada akhir dalam Gereja. Persekutuan Gereja Presbyterian di Amerika Serikat adalah salah satu dari banyak Gereja yang mengalami pergumulan ini.

Majelis Umum dari Gereja Presbyterian Amerika Serikat memberikan rekomendasi untuk mengubah konstitusi pernikahan yang awalnya mengatakan "komitmen antara dua orang, secara tradisional laki-laki dan perempuan" pada tahun 2014 dan disahkan pada tahun 2015 silam (Samosir, 2015). Usulan tersebut dihasilkan setelah para senior dan menteri Gereja melakukan pertemuan mengenai pernikahan sejenis dan benar-benar disahkan setelah pemungutan suara yang dilakukan di dalam Gereja tersebut. Hasil pemungutan mengatakan bahwa 86 suara setuju untuk mengubah kata-kata dari konstitusi pernikahan tersebut. Memang ada suatu kekhawatiran bahwa jemaat akan meninggalkan Gereja tersebut karena keputusan itu yang akhirnya terbukti. Gereja tersebut mencatat telah kehilangan lebih dari 500 ribu jemaat karena keputusan ini (Samosir, 2015). Namun meskipun begitu, Gereja Presbyterian tersebut tetap kukuh dengan keputusan mereka untuk memperbolehkan pernikahan sesama jenis.

Gereja di Indonesia pada umumnya masih memegang teguh teologi-teologi yang mengajarkan bahwa homoseksual itu adalah sebuah dosa. Contohnya seperti Gereja yang khususnya berada di Surabaya, seperti denominasi karismatik Bethany, Mawar Sharon, dan beberapa gereja lainnya. Kembali pada diri saya sendiri, saya pertama kali mengetahui isu homoseksual dari fanfictions atau singkatnya fanfic, adalah sebuah kumpulan atau rangkaian seri cerita fiksi. Layaknya cerpen, atau novel, tetapi dibintangi oleh tokoh idola. Awalnya, saya mengetahui isu homoseksual ini melalui fanfictions pada saat saya menduduki bangku SMP. Saat itu, boyband dan girlband asal Korea baru saja terkenal di sekolah saya dan tentu saja saya terikut dengan K-wave yang sedang mewabah dengan hebatnya. Saya yang memang senang membaca cerita fiksi, lalu ditambah lagi dengan tokoh idola yang saya senangi membintangi cerita-cerita tersebut; pastinya tidak akan saya lewatkan. Tidak jarang ceritacerita tersebut membuat setting ketika mereka bukanlah seorang idola dan menjadi orang biasa atau tetap menjadi idola dengan plot yang berubah tajam diakhir cerita.

Cerita yang paling saya ingat adalah ketika dua orang idola saya diceritakan sebagai kaum homoseksual. Dalam cerita tersebut, mereka diperlakukan tidak seperti layaknya pasangan pada umumnya. Mereka dicaci, dimaki, dijauhi, dan diisolasi masyarakat. Saya merasa terenyuh membaca cerita itu. Simpati terhadap apa yang mereka alami, hingga pada akhirnya mereka berpisah karena tekanan sosial yang menuntut mereka untuk berpasangan dengan lawan jenis. Cerita tersebut membuat saya berpikir dan melihat kenyataan di sekeliling saya pada waktu itu.

Teman-teman saya membuat banyak lelucon yang merendahkan kaum homoseksual 
dan membuat seakan-akan kalau homoseksual adalah hal yang buruk dan menjijikan. Beberapa kata yang saya ingat, "Ih, gay. Geli sukanya sama cowok",dan "Dasar gay, jauh-jauh sana!", "Dasar lesbi ke mana-mana masa berdua mulu! Najis!", dan lain-lain dengan nada yang merendahkan. Meskipun kata-kata tersebut candaan semata, hal ini membuat saya sadar bahwa peristiwa tersebut tidak hanya terjadi dalam fiksi semata, namun dalam dunia nyata juga. Kaum homoseksual selalu dianggap sebagai sesuatu yang abnormal dalam masyarakat yang mengagungkan nilai-nilai heteronormativitas, dan pada waktu itu saya benar-benar yakin bahwa masyarakat itu salah.

Seiring berjalannya waktu, pada satu hari Minggu saya mendengarkan sebuah khotbah bahwa umat Kristiani, khususnya di gereja tempat saya berjemaat pada waktu itu, menolak homoseksual. Saya kaget ketika mendengar itu. Saya yang waktu itu mendengarkan langsung merasa seperti telah melakukan kesalahan besar karena telah mendukung keberadaan mereka. Namun, di saat yang sama saya juga merasa saya tidak melakukan kesalahan apa-apa. Saya peduli terhadap mereka dan bukankah kita sebagai umat Kristiani diharuskan untuk menebar cinta kasih pada sesama? Tetapi, pada akhirnya tidak semudah itu membuat perasaan bersalah itu hilang. Di sinilah pertama kali konflik tersebut muncul.

Konflik ini berangsur-angsur tertimbun dengan persoalan lainnya yang saya hadapi dari waktu ke waktu hingga akhirnya muncul lagi ke permukaan ketika saya kuliah dan bertemu dengan teman yang memiliki orientasi homoseksual. Jujur saja, pada awalnya saya bingung bagaimana saya harus berinteraksi dengannya. Tetapi, lama-kelamaan saya merasa nyaman dan ia juga orang yang baik menurut saya. Jadi, kenapa enggak dijadikan temen? Meskipun saya kesulitan ketika ia sudah mulai berbicara mengenai orang yang disukainya. Saya tidak tahu apa yang harus dilakukan apa; apakah saya harus mendukungnya atau tidak. Karena di satu sisi ajaran Kristen selalu mengajarkan mengenai kasih. Kasih itu sabar, kasih itu murah hati-namun di sisi lain, kasih tersebut dilupakan karena 'menurut ajaran agama yang saya tahu homoseksual itu dosa, harus dijauhi' masih sangat jelas dibenak saya.

Dari dasar itulah penelitian ini, bagi saya, menjadi proses untuk berdamai dengan diri. Seperti yang telah diketahui sebelumnya, saya seorang Kristiani dan berkonflik terkait dengan ajaran agama Kristen yang saya ketahui. Jika berbicara mengenai ajaran agama, tentunya pendeta adalah orang yang tepat untuk ditanyakan mengenai hal tersebut. Pendeta diasumsikan sebagai seseorang yang tahu betul mengenai seluk beluk ajaran agama atau teologi Kristen. Untuk itu, saya akan menjadikan pendeta yang menerima dan menolak sebagai partisipan dari penelitian saya ini. Melalui upaya memahami proses yang dijalani seorang pendeta sehingga mereka memiliki sikap tertentu yang sangat kuat terhadap kaum homoseksual; menolak atau menerima, akan menolong saya untuk lebih mudah dalam menapakkan kaki di sisi menolak maupun menerima.

Pendeta yang akan dijadikan partisipan dalam penelitian ini berasal dari keyakinan yang berseberangan dalam isu homoseksual. Saya memilih dua pendeta tersebut karena mereka sama-sama memiliki keyakinan yang kuat mengenai ajaran Kristen yang mereka miliki meskipun berbeda. Perbedaan itu yang saya ingin ketahui.

Selain untuk diri saya sendiri, saya juga ingin menyajikan pengetahuan dan pengertian kepada masyarakat seputar isu homoseksual dari sisi pendeta. Tidak banyak yang mengetahui bahwa ada pendeta di Indonesia yang menerima homoseksual dan tidak banyak pula mereka yang mengetahui bahwa ada sisi lain dari isu homoseksual yang selalu dikatakan berdosa ini dari sisi pendeta yang menerima maupun yang menolak. Beberapa masih menganggap topik seputar homoseksual mungkin tidak seberapa penting sehingga jarang sekali dibahas, khususnya oleh kaum yang beragama Kristen, padahal nyatanya isu homoseksual makin banyak bermunculan di berbagai belahan dunia dan tidak dapat diabaikan lagi karena ini juga adalah bagian dari kehidupan bermasyarakat. 
Ada tiga pertanyaan penelitian yang saya ajukan: bagaimana terbangunnya pemaknaan seorang tokoh pemuka agama Kristen mengenai homoseksualitas; bagaimana dialog intrapersonal berbasis pengalaman keseharian, pengetahuan dan teologi kekristenan membentuk keyakinan akan homoseksualitas; bagaimana pemaknaan tersebut mewarnai keseharian dari seorang pemuka agama Kristen.

\section{METODE}

Dalam penelitian ini saya akan mendalami proses bagaimana suatu pemaknaan-yaitu pemaknaan terkait dengan isu homoseksual, terbentuk dalam diri seorang pendeta yang akhirnya tergambar dari perilaku yang ditampakkan. Pemaknaan tersebut akan menyangkut penerimaan dan penolakan homoseksual. Teknik pengambilan data dilakukan melalui wawancara dengan metode wawancara semi-terstruktur dan data wawancara yang didapatkan akan dianalisis menggunakan Teknik analisis tematik.

Jumlah pemuka agama atau pendeta yang saya wawancarai pada penelitian adalah sebanyak dua orang. Satu pendeta yang menolak dan satu pendeta yang menerima homoseksual. Cara saya mencari beberapa pendeta tersebut adalah dengan mencari pendeta yang memang sudah terkenal dengan pemikiran mereka tersebut terkait homoseksualitas.

Dalam penelitian ini saya juga akan membahas seputar ajaran agama. Ajaran yang dibahas dalam tulisan ini adalah ajaran agama Kristiani. Hal-hal yang berhubungan dengan teologi yang ditulis dalam penelitian ini hanyalah ajaran yang berkenaan dengan isu homoseksual.

\section{HASIL DAN BAHASAN}

Ada dua pendeta yang diwawancarai dalam penelitian ini. Pendeta yang menerima homoseksual bernama Ben dan yang menolak bernama Eli. Mereka datang dari dua latar belakang kehidupan yang berbeda. Ben berasal dari Jakarta sedangkan Eli berasal dari salah satu desa di Jawa Timur.

Pandangan mereka tersebut terbentuk atas rangkaian pengalaman yang mereka miliki secara pribadi masing-masing. Setelah melewati masa-masa kehidupan dan belajar hal-hal yang berkaitan dengan isu homoseksual, akhirnya mereka mendapatkan suatu konklusi bahwa Ben menerima homoseksual sedangkan Eli menolak homoseksual dengan keras. Definisi mengenai homoseksual dari mereka tidak jauh berbeda jika dilihat secara garis besar. Mereka sama-sama melihat bahwa homoseksual adalah bentuk ketertarikan terhadap sesama jenis. Hal yang membedakan hanya Eli yang tidak mengangkat hal mengenai hetenormativitas sedangkan Ben mengangkat hal tersebut dalam jawabannya. Terlihat bahwa Ben lebih peka terhadap norma-norma yang berlaku di masyarakat.

Ada hal yang menurut saya menarik untuk dilihat dalam jawaban Ben ketika ditanya mengenai definisi homoseksual, yaitu "heteronormativitas (...) biasa diberlakukan di masyarakat kita". Melihat realitas di sekitar, memang tidak dapat dipungkiri bahwa mayoritas masyarakat menekankan budaya heteronormatif. Secara singkat, menurut Blumenfeld heteronormativitas didefinisikan sebagai sebuah asumsi bahwa hanya ada satu orientasi seksual yang valid yaitu heteroseksual (dalam Dreyer, 2007). Budaya ini begitu kental, begitu melekat di dalam masyarakat yang akhirnya memunculkan bibit-bibit penolakan terhadap hal yang pastinya berbeda di luar pemikiran heteronormatif, homoseksualitas.

Budaya ini pun juga terbukti dalam kehidupan Eli, partisipan kedua dan juga adalah seorang pendeta yang sampai sekarang benar-benar menolak keras homoseksual. Aneh, bagi Eli. Homoseksual adalah sesuatu yang asing - bahkan aneh. Bergaul di dalam lingkungan yang sangat menjunjung tinggi heteronormativitas, tidak dapat dipungkiri bahwa isu tersebut terasa asing di telinganya.

Sama seperti Ben, Eli juga menunjukkan suatu antusiasme ketika saya memintanya 
untuk menjadi partisipan dalam penelitian saya ini. Menurutnya, isu homoseksual adalah hal yang membuatnya tergerak karena isu ini, baginya, adalah sesuatu yang mendukakan hati Tuhan.

Teologi dan ajaran yang dianut menjadi hal yang sangat penting untuk dibahas ketika pendeta menjadi fokus utama. Pendeta adalah seorang agen utama dalam menyebarkan ajaran dan teologi yang dianggapnya benar.

Seperti yang telah diketahui, Ben adalah pendeta yang menerima homoseksual. Menurut Ben, kaum homoseksual tidaklah berbeda dengan kaum lainnya hanya karena orientasi seksual yang mereka miliki. Oleh karena itu, tidak sepantasnya mereka ditolak masyarakat. Hal ini, menurutnya, adalah semua rangkaian dari keyakinan yang ia miliki.

Jika melihat dari sisi teologi yang diterima oleh Ben-yaitu ajaran peace church yang menekankan pada kedamaian dan menganggap seluruh kekerasan dan perang adalah dosa, digambarkan bahwa Yesus selalu ada untuk kaum-kaum yang terpinggirkan. Kitab suci juga menjelaskan dengan gamblang mengenai hal tersebut. Dituliskan bahwa kaum-kaum terpinggirkan yang ada pada zaman Yesus adalah orang miskin (Luk 1: 52-53), orang sakit kusta (Luk 17: 11-19) dan kisah Zakeus sang pemungut cukai (Luk 19). Dalam ayat-ayat kitab suci, mereka selalu mendapatkan diskriminasi-diskriminasi sosial dari berbagai pihak.

Dengan dasar pengetahuan dan pengertian tersebut serta melihat keadaan lingkungan yang begitu menekan komunitas dan kaum LGBT, Ben menerapkannya dalam konteks masa kini dan menginternalisasi ajaran tersebut sebagai norma personal yang dimilikinya. Ben melihat masyarakat Indonesia, media dan pemerintah dalam memperlakukan kaum-kaum LGBT masih sangat miris. Kaum LGBT akhirnya, dalam kacamata Ben, menjadi kaum yang terpinggirkan di era ini dan ia merasa harus menerima dan membela mereka.

Ajaran agama yang dianut Eli adalah ajaran yang bisa dikatakan mainstream, bukan hanya di Indonesia namun juga di sebagian besar ajaran Kristen di dunia. Ajaran ini mengatakan bahwa firman-firman yang ada di kitab suci menujukkan sebuah penolakan dan dengan keras mengutuk perilaku-perilaku yang berkaitan dengan homoseksual. Sama seperti ajaran yang dianut oleh Ben yang mengatakan bahwa topik-topik mengenai homoseksual jarang dibahas, Eli juga mengatakan demikian namun dengan perspektif yang berbeda. Jika Ben melihat bahwa homoseksual itu jarang dibahas dan tidak ada larangan-larangan yang jelas mengatakan bahwa homoseksual adalah dosa. Eli mengatakan sebaliknya, homoseksual adalah sebuah dosa, dan juga sebuah penyimpangan seksual.

Eli mendapatkan pengertian tersebut dari kisah Sodom dan Gomora dan beberapa ayat lainnya serta khotbah di gereja. Kisah mengenai Sodom dan Gomora adalah kisah yang paling sering diangkat ketika membicarakan mengenai hal-hal yang berhubungan dengan kaum dan perilaku homoseksual. Kisah tersebut menceritakan mengenai kota Sodom dan Gomora yang lenyap karena dosa yang dilakukan oleh penduduk kota-kota tersebut. Dari beberapa dosa yang disebutkan, perilaku yang berkaitan dengan homoseksual ada di sana sehingga halhal yang berkaitan dengan perilaku homoseksual akhirnya juga dianggap sebagai sebuah dosa. Selain mengutuk perilaku homoseksual, Eli juga menolak mereka yang mendukung homoseksual dengan mengantongi hal yang ia pelajari berdasarkan dari kitab Wahyu.

Ben dan Eli bukanlah yang pertama kali memiliki keyakinan demikian. Teologi mainstream, yang dipegang Eli dan teologi queer memayungi hal yang berhubungan dengan homoseksual, yang dipegang oleh Ben telah ada dari sebelum-sebelumnya. Jika teologi mainstream dari turun temurun menolak homoseksual, teologi queer di sisi lain menerima mereka. Seperti yang saya sebutkan di atas, keyakinan mereka adalah hasil dari rangkaian pengalaman-pengalaman yang mereka miliki.

Ada tiga masa yang dimiliki oleh Ben dan Eli yang berkaitan dengan isu homoseksual, yakni masa SMA, masa berkuliah dan masa ketika mereka bekerja hingga sekarang ini. Umur Ben dan Eli memang terpaut cukup jauh, namun mereka sama-sama mengetahui isu 
homoseksual ketika mereka menginjak usia remaja tepatnya saat menduduki bangku SMA. Saat itu, mereka sama sekali tidak mengerti apa itu homoseksual. Hanya mendengar dari sekitar mereka saja.

Sebelum Ben menerima homoseksual seperti sekarang ini, ia dulunya sama seperti Eli menolak dengan keras hingga mengatakan bahwa dirinya seorang homophobic dan ia sering membicarakan topik ini, namun konteksnya negatif. Istilah homoseksual dijadikan bahan olokolokan dan merendahkan.

Dari pengalaman Ben tersebut dapat tergambar bahwa ada stereotip-stereotip tertentu yang muncul terkait dengan laki-laki feminin dan homoseksual. Di sini istilah homoseksual lebih banyak terikat pada identitas laki-laki dibandingkan dengan perempuan. Selain itu, menurut penelitian yang dilakukan oleh Fingerhut dan Peplau (2006) yang berjudul The Impact of Social Roles on Stereotypes of Gay Men menemukan bahwa kaum gay sering dan pada umumnya diinterpretasikan sebagai kaum yang memiliki sifat feminin. Laki-laki dituntut untuk menjadi kuat oleh masyarakat yang menjunjung tinggi heteronormatif. Mereka dituntut untuk tidak memperlihatkan perasaan dan perilaku tertentu yang identik dengan sifat feminin atau sifat keperempuanan. Ketika seorang laki-laki menunjukkan sifat-sifat yang secara garis besar dapat dikategorikan sebagai karakteristik yang feminin dan hal tersebut merusak frame dari maskulinitas yang telah terbentuk, akhirnya mereka diasosiasikan dengan kaum homoseksual.

Masih dalam konteks yang sama, laki-laki feminin dianggap sebagai hal yang aneh. Tidak normal untuk laki-laki berperilaku atau bersikap layaknya perempuan. Dengan dasar ini, istilah homoseksual lalu dijadikan sebagai istilah untuk memperolok dan merendahkan seseorang khususnya dalam konteks pengalaman Ben, seorang laki-laki.

Ada proses belajar ketika Ben melihat peristiwa-peristiwa perundungan yang 'terkait' dengan isu homoseksual. la melihat bahwa homoseksual adalah hal yang tidak diterima oleh teman-temannya. Suatu hal yang dijadikan bahan perundungan. Teman adalah komponen yang berperan penting dalam merangkai pandangan Ben mengenai homoseksual.

Sedangkan dari sisi Eli, ia mengetahuinya dari berita acara malam. Acara berita malam sendiri, sungguh identik dengan mengabarkan isu-isu yang kontroversial dan tabu di masyarakat. Tidak semua orang bisa mengonsumsi berita-berita tersebut karena ditayangkan pada malam hari. Hanya orang-orang yang melek hingga larut yang bisa menyaksikan berita berita tersebut dengan kata lain, hanya orang dewasa yang bisa menyaksikan acara itu.

Di awali rasa ingin tahu, Eli cukup kaget setelah terpapar informasi seputar homoseksualitas. Dia terheran-heran. Semua informasi yang ia terima terasa sangat aneh, melihat seputarannya yang selalu berpasang-pasangan laki-laki dan perempuan. Eli yang telah mendapatkan gambaran cukup mengenai homoseksualitas pada saat itu, tidak mengatakan dirinya menolak atau menerima. Hanya saja, Eli merasa bahwa menyukai sesama jenis itu tidak wajar. Laki-laki menyukai laki-laki terasa aneh dan seperti halnya juga perempuan yang menyukai perempuan.

Kembali pada Ben, pandangannya mengenai ketidaksenangannya terhadap kaum homoseksual pun dikuatkan oleh lingkungan tempat bersekolahnya kemudian. Setelah menyelesaikan pendidikan SMA di Indonesia, Ben lalu pergi bersekolah di suatu sekolah teologi di Singapura. Negara tersebut terkenal dengan aturan yang ketat dan kekentalan dari budayanya yang konservatif. Sekolah teologi tempat Ben menimba ilmu pun termasuk memegang kekristenan yang juga konservatif.

Pengalaman serupa atau pengalaman yang berkaitan dengan isu homoseksual tidak muncul pada Eli ketika ia menduduki bangku perkuliahan. Topik mengenai isu homoseksual tidak begitu digubrisnya pada saat ia berkuliah karena pada waktu itu fokus yang dimilikinya jauh lebih kepada keluarganya yang baru saja ditinggalkan oleh ayahnya. Sehari sebelum Eli meninggalkan rumah untuk pergi berkuliah di sekolah teologi Surabaya, ayahnya yang seorang 
pendeta tiba-tiba meninggal. Eli memiliki ikatan yang kuat dengan almarhum sehingga hal itu tentu sangat membuatnya terpukul. Karena sangat terpukul, isu mengenai homoseksual terkubur dengan isu tersebut yang lebih dekat dengan dirinya pada waktu itu.

Pandangan Ben mengenai homoseksual tidak selamanya negatif. Memang tidak langsung berubah 180 derajat, tetapi pandangan Ben tersebut berangsur-angsur berubah menjadi pandangannya yang menerima seperti sekarang ini. Namun hal ini berbeda dengan Eli. Sejak awal Eli yang merasa bahwa homoseksual adalah sesuatu yang aneh, akhirnya dikuatkan dengan pengalaman-pengalaman hidupnya yang berikutnya.

Setelah Ben menyelesaikan pendidikan sarjananya, Ben melanjutkannya ke jenjang pendidikan berikutnya di Amerika. Sekolah teologi yang dituju oleh Ben adalah sekolah teologi yang tergolong dalam peace church Brethren. Gereja tersebut bergerak dalam pengembangan ajaran mengenai Christian Pacifism yang mengatakan bahwa kekerasan dan perang tidak sejalan dengan ajaran dan kehendak Kristus (González, 2005).

Dalam sekolah tersebut, Ben melihat bahwa institusi menerima mahasiswa mereka yang LGBT dengan baik. Datang dari lingkungan pertemanan di sekolah yang benar-benar mengenyampingkan, menolak, hingga melecehkan homoseksual lalu datang dan menetap di sekolah yang menerima dengan baik orang-orang LGBT, tentu saja ada perubahan signifikan yang dirasakan Ben. Tidak mudah tentunya untuk langsung mengubah homophobia yang telah terpatri dalam belief yang dimilikinya.

Ben, yang pada awalnya belum pernah berhadapan dan berintertaksi langsung dengan kaum homoseksual, lalu benar-benar terjun dalam sebuah Ingkungan yang benar-benar mendukung membuat segala prasangka dan belief negatif yang dimiliki Ben mengenai kaum homoseksual berangsur menghilang. Menurut teori yang dikemukakan oleh Allport (dalam Pettigrew, 1998) mengenai kontak intergrup, prasangka atau bias terhadap suatu kelompok atau individu dapat berkurang ketika adanya kontak antar-kelompok atau antar-kedua belah pihak yang memiliki masalah. Ada empat syarat yang harus terpenuhi agar dampak positif tersebut dapat terjadi, yaitu status yang seimbang dalam suatu situasi, ada tujuan bersama yang hendak dicapai, kerja sama antar-grup dan adanya dukungan dari pihak otoritas, hukum atau budaya (Pettigrew, 1998).

Dalam hal ini, Ben memiliki status yang sama sepadan. Ben adalah seorang pendatang baru di Amerika, khususnya di lingkungannya tersebut, belum pernah bertemu dengan kaum gay sebelumnya dan memiliki prasangka-prasangka tertentu. Sementara, teman gay yang baru saja dikenalnya adalah pendatang dalam situasi kehidupan Ben. Kedua, tujuan yang dimiliki oleh kedua belah pihak, Ben dan teman gay Ben tersebut, adalah sama, yaitu untuk saling mengenal satu dengan yang lainnya. Kerja sama dari kedua belah pihak pun juga ada dan terlihat dari Ben yang meskipun tidak menyukai kaum homoseksual tetap berperilaku sopan dan baik seperti halnya dari teman Ben yang berlaku baik. Lalu syarat yang terakhir, meskipun tidak ada pihak otoritas dan hukum yang mendukung di dalam interaksi mereka, budaya yang ada di sekitar Ben mendukung homoseksualitas. Budaya tersebut menjadi 'hukum' yang membuat Ben tidak bisa berlaku seperti apa yang dirasakannya dan ketika mereka mulai mengenal satu sama lain lebih jauh, bias dan prasangka Ben mengenai kaum homoseksual pun menurun, karena prasangka-prasangka yang dimiliki Ben tidak terbukti selama interaksi mereka berjalan.

Terbiasa dengan lingkungan sekolahnya dan interaksinya dengan beberapa teman dari kaum LGBT, Ben secara bertahap mulai menerima homoseksualitas. Dari yang awalnya tidak menerima, tidak nyaman melihat gerak-gerik mereka, merasa jijik dan takut, akhirnya menjadi menerima. Prasangka-prasangka yang ia miliki berangsur-angsur hilang.

Pada titik ini, Ben telah memiliki pandangan bahwa homoseksual itu sama saja dengan heteroseksual. Berbeda dengan Ben, Eli yang bertumbuh dewasa sedikit demi sedikit mulai mendapatkan pengajaran-pengajaran mengenai isu homoseksual yang dibahas dalam konteks 
ajaran agama dalam khotbah ibadah-ibadah yang ada di gereja. Melihat ajaran agama Kristen yang mainstream di Indonesia adalah ajaran yang mengutuk perilaku-perilaku homoseksual, akhirnya Eli membuat keputusan bahwa ia menolak homoseksualitas karena menurutnya hal tersebut adalah sebuah dosa yang mendukakan hati Tuhan.

Ada proses internalisasi norma deskriptif pada Eli. Norma deskriptif yang ada di kehidupannya adalah penolakan terhadap homoseksual. Karena dikelilingi oleh ajaran agama dan orang-orang yang menentang keras dan mentabukan homoseksual ditambah lagi dengan Eli yang juga tidak pernah melakukan interaksi langsung dengan mereka menghasilkan dominasi yang kuat atas norma deskriptif tersebut. Menolak homoseksual menjadi satusatunya hal yang ia ketahui.

Belief yang dimiliki Eli lalu dikuatkan dengan melihat pengalaman orang-orang di sekeliling dirinya. Seiringnya perkembangan jaman, kaum homoseksual jauh lebih terbuka dari pada sebelumnya. Salah satu peristiwa yang ia ingat adalah ketika peristiwa mengenai sepasang suami istri yang suaminya adalah seorang gay dan menggunakan pernikahan sebagai kedoknya. Eli yang melihat peristiwa itu, merasa iba dengan keadaan istri seorang gay tersebut yang menurutnya sangat menyedihkan-seperti memahami sebagai satu perempuan ke perempuan lainnya.

Lalu ada pengalaman lainnya yang juga dilihat Eli yakni ketika seorang perempuan terkhianati oleh suami yang berorientasi homoseksual di sebuah sekolah Alkitab Surabaya. Ada sebuah proses belajar yang terwakilkan lewat pengalaman istri-istri dari para suami gay tersebut. Beberapa pengalaman orang lain yang dilihat Eli ini sungguh membuatnya prihatin. Eli selalu melihat hal tersebut dari sisi perempuan. Betapa sedih dan menderitanya sang istri yang diduakan oleh suaminya dengan laki-laki lain. Hal ini cukup membuat Eli kesal dan terbebani.

Hal ini akhirnya mengukuhkan pendapat Eli sudah beranggapan bahwa homoseksual adalah hal yang aneh, sesuatu yang tidak biasa, abnormal dan tidak mendidik bagi generasigenerasi selanjutnya. Homoseksual diartikan sebagai suatu gaya hidup yang menyesatkan.

Setelah mereka berdua memiliki pandangan yang kuat mengenai homoseksual, tentu sebagai seorang pendeta mereka mengaplikasikan hal tersebut pada tugas mereka sebagai seorang pendeta.

Menjadi aktivis LGBT, adalah salah satu cara yang dilakukan Ben dalam menyuarakan kebenarannya tersebut. Sebagai aktivis LGBT, ia tidak hanya berurusan dengan isu-isu seputar homoseksual saja namun juga isu-isu lain yang dipayungi LGBT. Jika melihat beberapa fenomena yang terjadi di Indonesia seputar LGBT, khususnya mengenai homoseksual, memang dapat dikatakan miris dan Ben juga melihat realitas tersebut demikian. Ben adalah salah seorang dari kelompok-kelompok allies yang ada di Indonesia. la banyak memberikan kontribusi dalam kegiatan-kegiatan yang akan membantu kaum LGBT.

Aktivitasnya di dalam isu LGBT diawali ketika ia baru saja pulang dari Amerika setelah menyelesaikan pendidikan S2-nya. la kembali bekerja di sekolah teologi yang dulunya juga sekolah tempat ayahnya bekerja. Ketika Ben kembali bekerja, ia teringat dengan metode yang dibagikan oleh pendeta-pendeta di Amerika ketika ia menempuh pendidikannya dulu. Akhirnya, ia membuat suatu program untuk mahasiswanya agar bisa berkenalan dengan kaum homoseksual lebih dekat.

Kepeduliannya terhadap kaum homoseksual yang ada di Indonesia terus-menerus ia kembangkannya dan hingga pada hari ini banyak hal yang sudah dilakukannya, mulai dari membuat pelatihan hingga mengadakan acara-acara besar di sekolah teologinya untuk mengajak dan membangun interaksi antara kaum homoseksual dan masyarakat yang masih memiliki prasangka-prasangka negatif terkait dengan homoseksual.

Ajaran-ajaran peace church yang ia dapatkan ketika bersekolah di Amerika diinternalisasi olehnya sehingga menjadi sebuah norma personal. Norma ini adalah belief yang 
dimiliki seseorang terkait dengan kewajiban moral untuk melakukan perilaku spesifik (Schwartz dalam de Groot, Abrahamse, \& Jones, 2013). Norma ini tidak dapat diganggu oleh normanorma sosial, sehingga apapun yang dihadapkan dan dimana pun individu ditempatkan pola perilaku spesifik yang muncul tidak akan sama dengan sekitarnya. Hal ini bisa dilihat dalam perilaku Ben yang tidak lagi menolak kaum gay ketika kembali ke Indonesia. Norma sosial yang berlaku di Indonesia tidak mengubah perilakunya karena seperti yang sudah diketahui, Indonesia masih sangat menolak homoseksual.

Lain halnya dengan Ben, Eli menjalankan tugas kependetaannya menjadi seorang konselor yang dibawahi oleh gereja. Seperti yang diketahui sebelumnya, Eli adalah pendeta yang menolak homoseksual dan ia melihat bahwa homoseksual adalah sebuah dosa. Konseling yang dipegangnya tidak dikhususkan untuk kaum homoseksual. Semua orang yang memerlukan bantuan akan disambut, tidak perduli permasalahan apapun yang dibawa kepadanya.

Selama praktiknya menjadi seorang konselor, ia sudah dua kali memberikan konseling pada kaum homoseksual. Pada waktu inilah pertama kali Eli benar-benar bersentuhan secara langsung dengan mereka. Dari yang sebelumnya tidak pernah bertemu, lalu bertemu dengan mereka pertama kali dalam interaksi antara konselor dan klien.

Ketika Eli bertemu dengan mereka dalam konteks ini, di sinilah keyakinannya tersebut dipraktikkan.Sama seperti Ben, memang Eli juga bertemu dan bersentuhan secara langsung dengan kaum homoseksual. Namun hal yang membedakan di sini adalah Eli berusaha untuk 'menyembuhkan' dan menuntun ke jalan yang benar sesuai dengan keyakinannya tersebut sedangkan Ben berusaha untuk menolong mereka.

\section{SIMPULAN}

Penelitian ini mencoba untuk melihat lebih dalam dari dua sisi pendeta yang menerima maupun pendeta yang menolak homoseksual, dan tidak melihat pandangan mereka soal isu tersebut hanya dari keyakinan mereka yang sudah jadi. Proses bagaimana isu homoseksual menyentuh mereka, prosesnya ketika mereka menerima dan mengolah isu tersebut hingga menjadi suatu pandangan tertentu serta penerapan dari pandangan terhadap isu homoseksual menjadi sangat penting ketika kita membicarakan soal pendeta karena mereka adalah agen utama dalam menyebarkan ajaran-ajaran agama yang menurut mereka adalah suatu 'kebenaran'.

Dari hasil yang ditemukan, pemaknaan yang dimiliki oleh Ben dan Eli mengenai homoseksual memang berbeda. Ben, pendeta yang menerima, melihat bahwa homoseksual bukanlah suatu dosa dan mereka adalah kaum yang terpinggirkan. Sedangkan Eli, melihat bahwa homoseksual adalah sebuah dosa dan tidak mendidik. Keyakinan mereka ini terbentuk karena pengalaman selama mereka hidup dan bersentuhan dengan isu tersebut. Pengalamanpengalaman mereka ini akhirnya membentuk norma personal yang pada awalnya adalah suatu norma sosial baik norma injungtif maupun deskriptif.

Jika dikaitkan dengan teori sistem ekologi yang dikemukakan oleh Bronfenbrenner, norma-norma sosial ini termasuk makrosistem, yakni ajaran agama yang menerima maupun yang menolak, lalu juga ada nilai-nilai dari heteronormativitas termasuk di dalamnya. Mikrosistem yang dimiliki oleh Ben dan Eli juga sangat membantu mereka dalam menginternalisasi norma-norma sosial di sekitar mereka.

Ben dan Eli memang bukan yang pertama kali memiliki keyakinan mengenai homoseksual. Mereka juga bukan yang pertama kali memunculkan pandangan dari sisi teologi terkait dengan isu tersebut. Mereka belajar terus-menerus melalui pengalaman hidup yang beragam. Ada hal-hal di dalam hidup mereka yang berkaitan dengan isu tersebut dan mereka anggap penting sehingga berpengaruh sangat kuat dalam mengambil posisi di dalam isu ini. Tidak hanya ada di sekolah, keluarga, peer group atau teman sepermainan, hingga media pun 
sangat bisa menjadi sumber untuk belajar.

Jika melihat kembali pengalaman Ben dan Eli, unsur ajaran agama hanyalah menjadi salah satu faktor ketika mereka mulai membentuk pandangannya. Lingkungan sekitar mereka ikut berperan dalam pembentukan pandangan tersebut. Ben misalnya, dulu menolak homoseksual karena ada prasangka tertentu dan hal ini dipengaruhi oleh lingkungan pertemanannya. Lalu juga ada Eli yang menolak untuk membicarakan isu tersebut dengan teman-teman sebayanya. Tabu, katanya, karena melihat isu tersebut diberita malam yang identik dengan isu-isu yang tabu.

Lalu ada hal lain juga yang perlu digarisbawahi, Ben dan Eli sama-sama bertemu dengan kaum homoseksual. Ben bertemu mereka ketika ia mengambil studi S2-nya dan membuatnya menerima kaum gay. Sementara Eli bertemu mereka ketika berhadapan secara langsung dengan kliennya yang gay. Eli tetap bersikukuh dengan pandangannya bahwa homoseksual adalah sebuah dosa. Tentu menjadi pertanyaan mengapa mereka sama-sama bertemu secara langsung dengan kaum homoseksual tetapi Ben menjadi menerima dan Eli tetap menolak. Hal ini dikarenakan tipe interaksi mereka yang berbeda. Di dalam konteks Ben, mereka menjalin interaksi di level yang sama, egaliter. Sedangkan Eli menjalin interaksi antara konselor dan klien yang mengindikasikan bahwa adanya sesuatu yang bermasalah di dalam diri seorang homoseksual. Orang datang kepada Eli untuk memecahkan permasalahan yang ia miliki sehingga bukannya mengubah, tetapi malah semakin memperkuat bahwa homoseksual adalah sesuatu yang salah dan berdosa.

Seperti yang telah diketahui, penelitian ini adalah penelitian kualitatif, sehingga hasil yang didapatkan tidak dapat mewakili semua pendeta yang menerima maupun yang menolak homoseksual. Perlu ada kajian penelitian yang lebih jauh mengenai isu homoseksual dan kaitannya dengan agama. Seperti kaitan antara religiusitas dengan homophobia, atau kaitan antara religiusitas dengan penerimaan dan penolakan homoseksual, tidak hanya pada pendeta namun juga pada masyarakat umum. Selain itu, saya juga menyarankan untuk peneliti-peneliti di masa depan juga membahas lebih jauh mengenai isu heteronormatif yang saya temukan dalam penelitian saya ini dengan agama serta penerimaan maupun penolakan homoseksual.

\section{PUSTAKA ACUAN}

Bennett, LR 2005, Women, Islam and modernity: Single women, sexualityand reproductive health in contemporary Indonesia, Doi: https://doi.org/10.4324/9780203391389

Bronfenbrenner, U (1979), The ecology og human development, Harvard University Press, USA.

Cameron, D \& Berkowitz, B 2016, The state of gay rights around the world, Retrieved from https://www.washingtonpost.com/graphics/world/gay-rights/

de Groot, JIM, Abrahamse, W \& Jones, K 2013, 'Persuasive normativemessages: the influence of injunctive and personal norms on using freeplastic bags', Journal of Sustainability, 5, 1829-1844, Doi: https://doi.org/10.3390/su5051829

Dreyer, Y 2007, 'Hegemony and the internalisation of homophobia caused by hetero normativity', HTS Teologiese Studies/Theological Studies, 63(1), Doi: https://doi.org/10.4102/hts.v63i1.197

Erdianto, K 2016, 'Arus pelangi catat 142 serangan terhadap LGBT pada awal tahun ini, Retrieved from http://nasional.kompas.com/read/2016/08/11/20580231/ arus.pelangi.catat.142.serangan.terhadap.lgbt.pada.awal.tahun.ini

Fingerhut, AW \& Peplau, LA 2006, 'The impact of social roles on stereotypes of gay men', Sex Roles: A Journal of Research, 55(3-4), 273-278. Doi: https://doi.org/10.1007/s11199006-9080-5.

González, JL 2005, Essential theological terms, Westminster John Knox Press, Louisville.

Pettigrew, TF 1998, 'Intergroup contact theory', Annual Review of Psychology, 49(1), 65-85, 
Doi: https://doi.org/10.1146/annurev.psych.49.1.65

Samosir, HA 2015, Gereja presbyterian as legalkan pernikahan sesama jenis, Retrieved from https://www.cnnindonesia.com/internasional/20150318160211-3440081/gerejapresbyterian-as-legalkan-pernikahan-sesama-jenis

Tim Viva 2010, Argentina legalkan pernikahan homoseks, Retrieved fromhttps://www.viva.co.id/berita/dunia/164991-argentina-legalkan-pernikahanhomoseks 